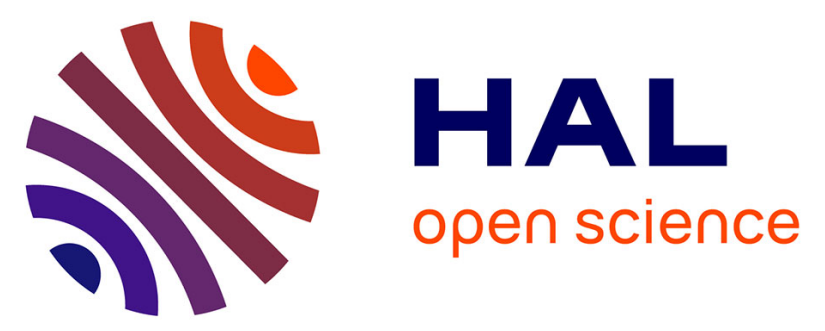

\title{
Variations of periphytic diatom sensitivity to the herbicide diuron and relation to species distribution in a contamination gradient: implications for biomonitoring
}

V. Roubeix, Nicolas Mazzella, L. Schouler, V. Fauvelle, Soizic Morin, Michel

Coste, François Delmas, C. Margoum

\section{To cite this version:}

V. Roubeix, Nicolas Mazzella, L. Schouler, V. Fauvelle, Soizic Morin, et al.. Variations of periphytic diatom sensitivity to the herbicide diuron and relation to species distribution in a contamination gradient: implications for biomonitoring. Journal of Environmental Monitoring, 2011, 13, pp.17681774. 10.1039/C0EM00783H . hal-00601815

\section{HAL Id: hal-00601815 https://hal.science/hal-00601815}

Submitted on 20 Jun 2011

HAL is a multi-disciplinary open access archive for the deposit and dissemination of scientific research documents, whether they are published or not. The documents may come from teaching and research institutions in France or abroad, or from public or private research centers.
L'archive ouverte pluridisciplinaire HAL, est destinée au dépôt et à la diffusion de documents scientifiques de niveau recherche, publiés ou non, émanant des établissements d'enseignement et de recherche français ou étrangers, des laboratoires publics ou privés. 


\title{
Environmental \\ Monitoring
}

Cite this: J. Environ. Monit., 2011, 13, 1768

wWW.rsc.org/jem

PAPER

\section{Variations of periphytic diatom sensitivity to the herbicide diuron and relation to species distribution in a contamination gradient: implications for biomonitoring}

\author{
Vincent Roubeix, ${ }^{* a}$ Nicolas Mazzella, ${ }^{a}$ Laurie Schouler, ${ }^{a}$ Vincent Fauvelle, ${ }^{a}$ Soizic Morin, ${ }^{a}$ Michel Coste, ${ }^{a}$ \\ François Delmas ${ }^{a}$ and Christelle Margoum ${ }^{a b}$
}

Received 24th December 2010, Accepted 4th April 2011

DOI: $10.1039 / \mathrm{c} 0 \mathrm{em} 00783 \mathrm{~h}$

\begin{abstract}
Diatoms are commonly used as bioindicators of trophic and saprobic pollution in rivers. However, more knowledge is needed concerning their sensitivity to toxicants such as agricultural herbicides. In this study, seven species of periphytic diatoms were isolated from the Morcille River (Beaujolais area, France) which presents a streamward contamination gradient by pesticides and particularly diuron. The sensitivity of these species to diuron was assessed through ecotoxicological tests based on shortterm growth inhibition of monospecific cultures. After application of an appropriate toxicological model, EC50 were determined and the species were ranked according to their tolerance. EC50 values ranged from 4.5 to $19 \mu \mathrm{g} \mathrm{L}^{-1}$. Finally, the results were related to field periphyton samples from an upstream and a downstream site in order to check if variations in specific relative abundance between sites are consistent with differences in tolerance to diuron. Species distribution between sites was only partially in accordance with toxicological results suggesting that other factors (toxic or trophic) have an important influence on diatom communities in the river. Nevertheless, diatoms showed their potential to indicate water contamination by pesticides and toxic indices could be developed in complement to existing trophic indices.
\end{abstract}

\section{Introduction}

Periphytic diatoms are often the dominant microalgae in river biofilm at the light-exposed surface of immersed substrates or sediments. They are easy to collect in the field and present high species diversity that can be analysed under the microscope by the observation of their characteristic siliceous frustules which encapsulate the cells. As they also have different sensitivities to pollution, diatoms are convenient organisms for bioindication in lotic systems and have been extensively used for river water

${ }^{a}$ Cemagref, UR REBX, F-33612 Cestas Cedex, France. E-mail: vincent. roubeix@cemagref.fr; vincent.roubeix@laposte.net; Tel: +33557890849 ${ }^{b}$ Cemagref, UR MALY, 3bis quai Chauveau, CP 220, F-69336 Lyon, France quality assessment, particularly in the European Water Framework Directive. ${ }^{1}$ Biological indices using diatoms have proved their ability to measure ecological alterations of rivers due to eutrophication or organic pollution (saprobity). However the current indices cannot account for river pollution by toxic compounds. It was suggested that diatom community variations may also reflect the presence of toxic stressors such as pesticides. $^{2-5}$ As plants, diatoms may be particularly sensitive to herbicides which are commonly found in rivers draining agricultural areas with peak concentrations in spring after field application and rain events. ${ }^{6}$

Diuron (3,4-dichlorophenyl)-1,1-dimethylurea is a herbicide which belongs to the phenylurea class. It is used in agriculture and especially vineyards to control undesirable weed growth. Its

\section{Environmental impact}

Pesticides used in agriculture contaminate rivers via runoff or spray drift. There is a need for biological indicators of contamination which can reveal an exposure to pesticides and an alteration of the ecosystem. Diatoms are well known bioindicators of eutrophication and organic pollution. It has been recently suggested that the composition of periphytic diatom communities may also inform about the presence of toxicants like pesticides in rivers. This could be possible if the sensitivity to pesticides of each diatom species was known. As a first step, this study used ecotoxicological tests to assess variations in sensitivity to one common herbicide (diuron) of various diatom species and checked if the results were consistent with species distribution in a highly contaminated river. 
physiological mode of action consists in the inhibition of photosynthesis via the blockage of electron transport in photosystem II. ${ }^{7,8}$ The presence of diuron has been reported in many freshwater systems all over the world and is the herbicide most often detected in French rivers. ${ }^{9}$

To date, the toxicity of diuron towards diatoms has been assessed in two different ways: (1) via short monospecific tests or (2) by the use of contaminated experimental channels and exposure of natural biofilm samples usually over a longer time scale. The first method allows the standard determination of toxicity parameters such as the $50 \%$ effect concentration (EC50) from the inhibition of growth or photosynthesis. However, these tests concern a small number of diatom species, mostly standard cultures and marine taxa, as diuron is also an antifouling agent. ${ }^{10-14}$ In the second approach, a large set of relevant species for the study area can be tested at the same time. Nevertheless the complex biotic interactions in diatom communities make the isolation of the toxic effect on individual species difficult, especially at low contamination levels. ${ }^{3,15}$

In order to use periphytic diatoms as bioindicators of water contamination by pesticides, variations in the sensitivity of diatom species have to be clearly demonstrated and these variations must lead to the classification of diatoms into groups of tolerance defined on a taxonomic (species or genus level, like current diatom indices) or an ecological basis (life forms) as recently proposed by Rimet and Bouchez. ${ }^{3}$ As a contribution to this objective, the present study independently compared the sensitivity to diuron of a few common diatom species isolated from the same river. Variations in sensitivity were then related to the distribution of these species along a contamination gradient (in the Morcille River) in order to check the hypothesis of bioindication: sensitive species have a lower relative abundance in communities where pollution is higher. The results led to a discussion of diatom's potential for the bioindication of pesticide contamination in rivers.

\section{Materials and method}

\section{Study area}

The Morcille River located in South-East France (Beaujolais area) is a shallow $1^{\text {st }}$-order river which presents a clear streamward contamination gradient by pesticides due to the large number of vineyards along its course. In recent years it has been extensively studied to assess the effect of toxicants on microbial communities. ${ }^{16-18}$ Diuron was identified as one of the major contaminants in the river. ${ }^{6}$ This study focused on an upstream site (Saint Joseph) not impacted by agriculture and a highly polluted downstream site (Saint Ennemond) (Fig. 1). In the upstream site neither diuron nor any other pesticide is usually detected..$^{2,19}$ Only 7 kilometres separate the two sites.

\section{Diatom community analysis}

Biofilm samples for the examination of diatom community composition were collected at both sites during spring campaigns on May $29^{\text {th }} 2008$ and June $16^{\text {th }} 2009$. The biofilm was scraped from artificial substrates (glass slides immersed for 2 and 1 month in 2008 and 2009 respectively) and suspended in spring water until return to the laboratory. Then the samples were

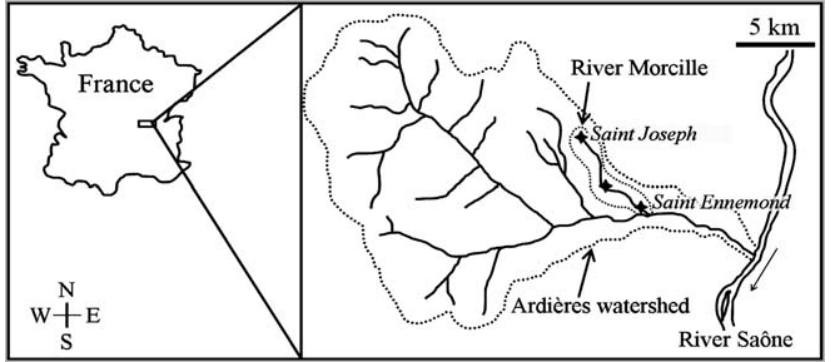

Fig. 1 Location of the sampling sites (St Joseph and St Ennemond) on the Morcille River.

digested in boiling $\mathrm{H}_{2} \mathrm{O}_{2}$ solution for complete oxidation of the organic matter. Diatom species were determined under the optical microscope $(1000 \times)$ from the observation of the siliceous frustules according to taxonomical literature ${ }^{20}$ and recent nomenclature updates. At least 800 individuals were counted from each biofilm sample to calculate species relative abundances in the communities.

\section{River chemical parameters}

During the period of substrate colonization, five water samples were regularly taken from both sites for determination of $\mathrm{pH}$, conductivity, dissolved organic carbon (DOC) and nutrients according to standard procedures. In 2008, diuron concentration was determined from the water samples by solid-phase extraction followed by liquid chromatography-tandem mass spectrometry (LC/MS/MS Series 1100 LC, Agilent, France and API 4000, Applied Biosystem, France). In 2009, time-weighted average concentrations of diuron were estimated by the use of polar organic chemicals integrative samplers (POCIS). The analytical methods are described in detail in Pesce et al. ${ }^{19}$ Copper concentrations in surface water were analysed by inductively coupled plasma mass spectrometry (ICP-MS, Thermo X7 series II) according to the standard method ISO NF EN 17294-2 (2005) with external calibration. Blanks and certified reference (TM28.3, lake water, Environment Canada) were systematically used to check the method accuracy.

\section{Diatom cultures}

Monospecific diatom cultures were obtained from two biofilm samples collected at the two sites in November 2009. The seven species considered in this study are listed in Table 1. The preparation of pure cultures of each species followed a two-step process. First a single cell was isolated in a sterile growth medium from a suspension of biofilm by micromanipulation. The population obtained was then grown in agarose (1\%). Finally a colony was extracted from the solid medium and cultured again in a liquid growth medium. This two-step process allowed the removal of most of the bacteria present in the biofilm.

The growth medium used for the cultures and tests was autoclaved $0.2 \mu \mathrm{m}$ filtered water from an unpolluted stream (Gèze River at Organ, $43.273^{\circ} \mathrm{N} 0.483^{\circ} \mathrm{E}$ ) enriched with WC nutrients. ${ }^{21}$ The species were maintained at $20{ }^{\circ} \mathrm{C}$ at $150 \mu \mathrm{mol}$ $\mathrm{m}^{-2} \mathrm{~s}^{-1}$ illumination with a $14: 10$ light : dark cycle. 
Table 1 Results of the ecotoxicological tests and other ecological parameters for the seven diatom species. Values in brackets are $95 \%$ confidence intervals. $R^{2}$ is the coefficient of determination of the non-linear regression performed on test results

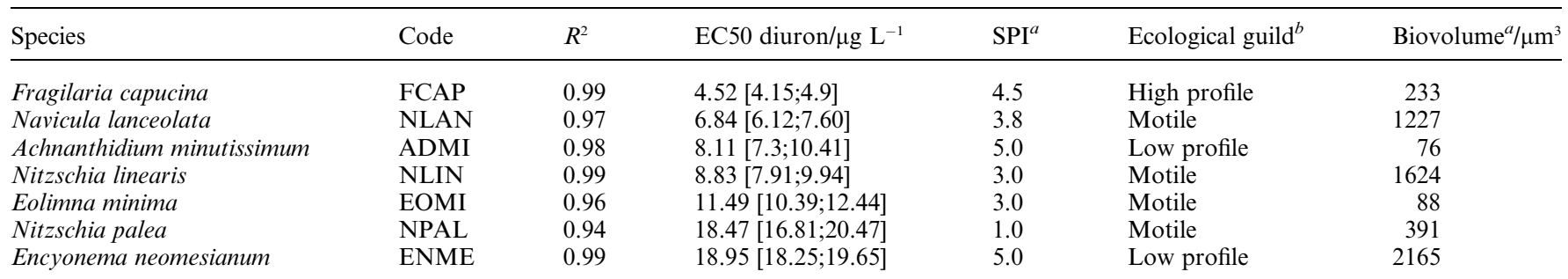

${ }^{a}$ Ominidia database. ${ }^{31}$ SPI: Specific Polluosensitivity Index. ${ }^{29}{ }^{b}$ Ref. 27.

\section{Ecotoxicological tests}

A concentrated solution of diuron was obtained by the complete evaporation of $5 \mathrm{~mL}$ of stock acetonitrile solution $\left(100 \mathrm{mg} \mathrm{L}^{-1}\right)$ and subsequent re-dissolution in $100 \mathrm{~mL}$ of culture medium. This solution was then sonicated for 1 hour, $0.2 \mu \mathrm{m}$ filtered and diluted into sterile growth medium to get five solutions at nominal diuron concentrations of $0.5,1.5,4.5,13.5$ and $40.5 \mu \mathrm{g}$ $\mathrm{L}^{-1}$. For each test, 15 autoclaved $50 \mathrm{~mL}$ glass bottles were filled with $30 \mathrm{~mL}$ of the diuron solutions in triplicates plus five control bottles with diuron-free growth medium. Finally $1 \mathrm{~mL}$ of a preconditioned exponentially growing culture of the species under study was added to the bottles which were placed on a rotating panel in a culture chamber at $23{ }^{\circ} \mathrm{C}$ with a $130 \mu \mathrm{mol} \mathrm{m} \mathrm{m}^{-2} \mathrm{~s}^{-1}$ illumination and a $14: 10$ light-dark cycle. The diatom biomass in the bottles was estimated by in vivo fluorescence, as a concentration of chlorophyll- $a$ (chl $a$ ) using a bbe FluoroProbe equipped with a $25 \mathrm{~mL}$ cuvette holder. Before pouring the contents of the bottles into the cuvette, the bottom of the bottles was gently rubbed with a brush to ensure complete resuspension of the benthic algae. The initial biomass was measured in an additional bottle and was at similar levels for each of the species tested $(0.4$ $3.8 \mu \mathrm{g}$ chl $a \mathrm{~L}^{-1}$ ). Diatom growth during the tests was assessed by the final biomass (in $\mu \mathrm{g}$ chl $a \mathrm{~L}^{-1}$ ) after $5 \pm 1$ days (according to the specific growth rate) when biomass started to be visible at the bottom of the bottles. The linear relationship between chla concentration measured by the fluorimeter and cell density counted using an optical microscope $(400 \times)$ had been checked previously (Schouler, unpubl. data; Roubeix et al. ${ }^{22}$ ). All tests were performed during summer 2010. The tested species were Achnanthidium minutissimum (Kützing) Czarnecki (ADMI), Eolimna minima (Grunow) Lange-Bertalot (EOMI), Fragilaria capucina Desmazières (FCAP), Navicula lanceolata (Agardh) Ehrenberg (NLAN), Nitzschia linearis (Agardh) W.M. Smith (NLIN), Nitzschia palea (Kützing) W. Smith (NPAL) and Encyonema neomesianum Krammer (ENME).

\section{Diuron concentration measurements}

Initial diuron concentrations were checked for each test from the five diuron solutions. Samples $(50 \mathrm{~mL}$ for the two lowest concentrations and $1 \mathrm{~mL}$ for the others) were stored frozen until analysis.

For the highest concentrations (i.e. 4.5, 13.5 and $40.5 \mu \mathrm{g} \mathrm{L}^{-1}$ ), $10 \mu \mathrm{L}$ of a diuron- $d_{6}$ (Dr Ehrenstorfer GmbH, Augsburg,
Germany) solution ( $\left.1 \mathrm{ng} \mu \mathrm{L}^{-1}\right)$ were added as an internal standard and the samples were only filtered with regenerated cellulose membranes $(0.45 \mu \mathrm{m})$ (Whatman, Versailles, France) prior to the liquid chromatography coupled with tandem mass spectrometry (LC-MS/MS) analysis. Regarding the lowest concentration (i.e. 0.5 and $1.5 \mu \mathrm{g} \mathrm{L}^{-1}$ ) a pre-concentration step was carried out by solid phase extraction (SPE) before the LCMS/MS analysis.

The SPE step was performed with Visiprep ${ }^{\mathrm{TM}}$ and Visidry ${ }^{\mathrm{TM}}$ systems from Supelco (Saint-Quentin Fallavier, France). The cartridges were conditioned with $5 \mathrm{~mL}$ of methanol $(\mathrm{MeOH})$ and $5 \mathrm{~mL}$ of ultrapure water (UPW). Then, $50 \mathrm{~mL}$ of water sample were passed through the cartridge and $5 \mathrm{~mL}$ of UPW (with $5 \%$ $\mathrm{MeOH}$ ) were used for cleaning the cartridge. SPE cartridges were dried for 15 minutes under a gentle stream of nitrogen and stored at $4{ }^{\circ} \mathrm{C}$ before the elution step. The elution was performed with two volumes of $3 \mathrm{~mL}$, firstly $100 \% \mathrm{MeOH}$, and then $\mathrm{MeOH}$ : ethyl acetate $75: 25(\mathrm{v} / \mathrm{v}) .10 \mu \mathrm{L}$ of a diuron- $d_{6}$ solution ( $\left.1 \mathrm{ng} \mu \mathrm{L}^{-1}\right)$ were added as the internal standard and the extract was then evaporated to dryness. Extraction of unfortified mineral water samples was performed simultaneously with a blank control. Following the analytical protocol, the sample extracts were reconstituted in $1 \mathrm{~mL}$ of the initial HPLC eluent mixture (acetonitrile : UPW $90: 10(\mathrm{v} / \mathrm{v}))$.

An HPLC Ultimate 3000 (Dionex, Voisins-le-Bretonneux, France) coupled with a triple quadripole mass spectrometer API 2000 (AB Sciex, Les Ulis, France) was used for the sample analyses. The chromatographic separation was done on a Gemini-NX C18 $3 \mu \mathrm{m}, 110 \AA$ A, $100 \mathrm{~mm} \times 2 \mathrm{~mm}$ equipped with a SecurityGuard from Phenomenex (Le Pecq, France). The two eluents were acetonitrile (A) and ultrapure water with $5 \mathrm{mM}$ ammonium acetate (B), and a linear gradient was used: $10 \%$ of A for $1 \mathrm{~min}$, reaching $30 \%$ of $\mathrm{A}$ after $4 \mathrm{~min}, 40 \%$ of A after $8 \mathrm{~min}$, $80 \%$ of $\mathrm{A}$ after $9.5 \mathrm{~min}$, followed by $80 \%$ of A until $10.5 \mathrm{~min}$, a decrease of $\mathrm{A}$ to $10 \%$ after $11 \mathrm{~min}$. Lastly, the initial composition $(10 \%$ of $\mathrm{A})$ was maintained for $4 \mathrm{~min}$. The total running time was $15 \mathrm{~min}$ and the flow rate was kept constant at $400 \mu \mathrm{L}$ $\min ^{-1}$. The selected reaction monitoring (SRM) mode was used for quantification of both the diuron $(233>72$ and $233>46$ SRM transitions) and the diuron- $d_{6}(239>78)$. The sample injection volume was $50 \mu \mathrm{L}$. Further details regarding sample preparation and analysis can be found elsewhere. ${ }^{23}$ The diuron concentration was also measured in the river water in which the biofilm was growing and it was found to be under the detection limit $\left(<0.01 \mu \mathrm{g} \mathrm{L}^{-1}\right)$. 
To estimate abiotic degradation of the diuron during the tests, diuron concentrations set initially at $30 \mu \mathrm{g} \mathrm{L}^{-1}$ were measured in two control bottles without algae after six days of incubation in the same conditions as the cultures. No significant decrease of diuron concentration was observed during this stability test.

Measured diuron concentrations were always lower than expected because of the low solubility of the herbicide and its unequal dissolution among tests in spite of the application of the same protocol each time. Thus, measured effective concentrations were used for data analysis instead of nominal values.

\section{Statistical analysis}

The results of the tests were analysed with $\mathrm{R}$ software ${ }^{24}$ and the minpack.lm package. The following model was used to fit the data by non-linear regression:

$$
\operatorname{chl} a_{\mathrm{f}}=\operatorname{chl} a_{0}+\frac{\alpha+\delta \cdot C_{\mathrm{tox}}}{1+\left(\frac{C_{\mathrm{tox}}}{g}\right)^{\beta}}
$$

where chl $a_{0}$ and chl $a_{\mathrm{f}}$ are initial and final diatom biomasses, $C_{\mathrm{tox}}$ is the concentration of diuron and $\alpha, \beta, \delta$, and $g$ are model parameters. This model derived from Hill model accounts for possible stimulation of the endpoint at low concentrations of the toxicant (hormesis). ${ }^{25}$ The fitted model was then used to numerically determine the $50 \%$ effect concentration (EC50) which was the specific toxicity parameter considered in this study. Finally a bootstrap analysis (10 000 simulations) on weighted residuals gave a $95 \%$ confidence interval for the EC50 values.

\section{Results}

\section{Monospecific biotests}

The model chosen fitted well with the toxicological data (Fig. 2, Table 1). For each diatom species growth inhibition occurred in the diuron concentration range tested (Fig. 2). At the highest diuron concentration, $\operatorname{chl} a_{\mathrm{f}}($ eqn (1)) was at most one third of the control level. An increase of $\operatorname{chl} a_{\mathrm{f}}$ was observed at low diuron doses in almost all cases. This apparent stimulation of growth was most striking for E. neomesianum (about 1/3 higher than control) and $N$. linearis. EC50 values ranged from 5 to $20 \mu \mathrm{g} \mathrm{L}^{-1}$ and three groups could be distinguished from their distribution (Fig. 3) with a factor of 2 between groups. First, one species (F. capucina) exhibited the highest sensitivity to diuron $(\mathrm{EC} 50=$ $4.5 \mu \mathrm{g} \mathrm{L}^{-1}$ ). Then four species ( $N$. lanceolata, A. minutissimum, $N$. linearis and $E$. minima) showed a close and intermediate sensitivity to the herbicide although E. minima appeared slightly more tolerant. Their EC50 values averaged $8.8 \mu \mathrm{g} \mathrm{L}^{-1}$. Finally two species, $N$. palea and E. neomesianum, were clearly more tolerant than the other species to the herbicide with EC50 values of 18.5 and $19.0 \mu \mathrm{g} \mathrm{L}^{-1}$ respectively.

\section{Species field distribution}

The relative abundance of the seven species in sampled diatom communities was very variable over years but the general trends observed between the upstream and downstream sites remained generally the same. A. minutissimum was always more abundant upstream (dominant species in the community) than downstream, like the two less represented species E. minima and F. capucina (except in 2008 for the latter). In contrast, the two Nitzschia increased in relative abundance from up to downstream every year. The species E. neomesianum was found only in 2009; it was generally rare in communities but was nevertheless more frequent upstream. Navicula lanceolata showed opposite trends for the two periods: its relative abundance was higher upstream in 2008 but downstream in 2009.

\section{Discussion}

\section{Variations in species sensitivity to diuron}

The acute toxicity tests based on growth inhibition demonstrated variations in sensitivity to diuron among the seven diatom species. The 4-parameter model used adequately described the complex effect of the herbicide on chla concentration at the end of the tests. Higher chla concentrations compared to controls at low diuron doses had already been observed in experimental channels with biofilm. ${ }^{15}$ This 'greening effect' may result from an adaptive increase of pigment production in microalgal cells to compensate for the reduction in photosynthetic efficiency caused by the herbicide. From our results, the extent of this adaptation can be estimated from the height and the broadness of the peak of chl $a_{\mathrm{f}}$ (Fig. 2, eqn (1)). Considering the two diatom species $F$. capucina and E. neomesianum (the most sensitive and the most tolerant to diuron respectively) it seems that the ability to adapt to low levels of the toxic compound determines the overall tolerance as measured by the EC50.

The EC50 values determined in this study fell within the range of values reported from ecotoxicological tests $\left(2.6\right.$ to $\left.169 \mu \mathrm{g} \mathrm{L}^{-1}\right)$ with monospecific diatom cultures ${ }^{11-14}$ or with river periphyton. ${ }^{15,19}$ There was a factor of 4 between the lowest and the highest values whereas a factor 7 was found for a group of eight marine diatoms. ${ }^{14}$ Much higher values were obtained with natural periphyton from the Morcille River, ${ }^{19}$ whose phototrophic community was composed of diatoms at $80 \%$. The Pollution Induced Community Tolerance (PICT) to diuron was illustrated by a 22-fold increase in EC50 from upstream ( $\mathrm{St}$ Joseph, $22 \mu \mathrm{g} \mathrm{L}^{-1}$ ) to downstream (St Ennemond, $486 \mu \mathrm{g} \mathrm{L}^{-1}$ ). This was originally thought to be due to the reduction downstream of sensitive species like A. minutissimum or E. minima and the development of more tolerant species like $N$. lanceolata. However, our results do not support this hypothesis since these species showed a similar sensitivity to the herbicide. Variations in the abundance of some microalgal species in the periphyton (not tested here) with a much higher tolerance to diuron may explain the tolerance increase of the phototrophic community. It is also likely that local adaptations of diatom species do occur in the river where pollution is the highest and that these adaptations were lost during the six months that elapsed between the isolation of the specimen population from the field and the date of the present tests. Indeed it was demonstrated that periphytic communities transferred from a contaminated to an unpolluted site recovered on a time scale of several weeks with a marked decrease in tolerance to herbicides. ${ }^{16,26}$

With a view to bioindication applications, it is interesting to relate the variations observed here in diuron sensitivity to 

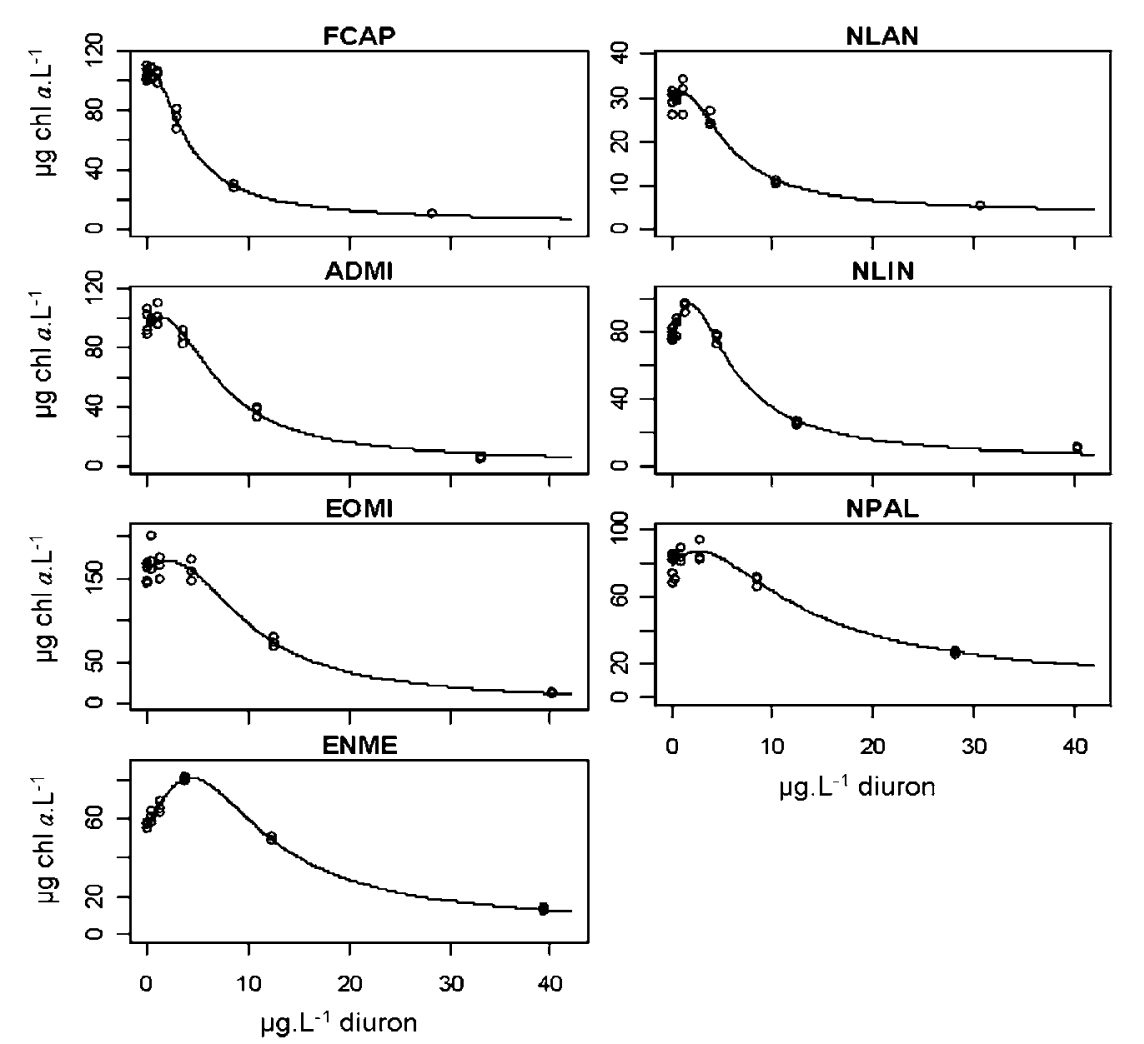

Fig. 2 Diatom biomass expressed in chlorophyll- $a$ at the end of the toxicological tests in relation to the diuron concentration. Species abbreviations are given in Table 1.

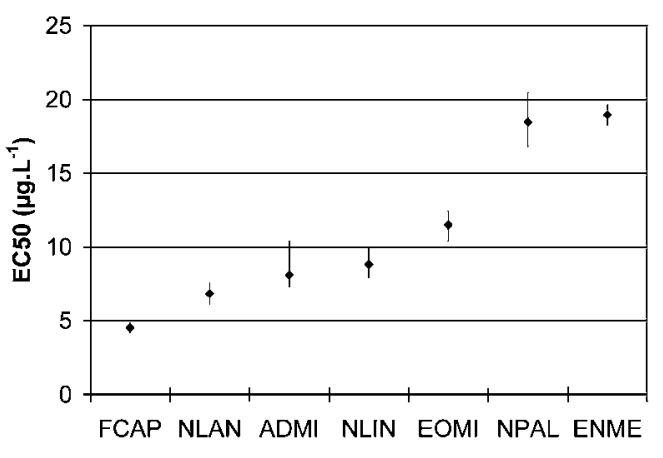

Fig. 3 Values of the EC50 with their 95\% confidence interval estimated for each diatom species from the toxicological tests with diuron. Species abbreviations are given in Table 1.

existing diatom classifications other than the classic taxonomy involving genera and species. Rimet and Bouchez ${ }^{3}$ proposed to use diatom life-forms and ecological guilds ${ }^{27}$ to assess pesticide contamination in rivers. Using mesocosms contaminated with diuron and fungicides they found that mobile species and species living in mucous tubules were favoured in the presence of toxicants at the expense of species belonging to the high profile guild. This is consistent with our results since $F$. capucina is a highprofile species forming ribbon-like colonies and the only strictly non-mobile taxon among those tested in this study. Moreover the ability to form mucous tubules is typical of the genus Encyonema. ${ }^{28}$ However the idea that mucous tubules constitute a protection for the diatoms against dissolved toxicants ${ }^{3}$ cannot be confirmed here because the cells of E. neomesianum did not form mucous tubules in our tests probably as a result of the absence of current in the culture bottles. Finally the reduction of diatom size with contamination by diuron was reported ${ }^{3,15}$ and this led to the conclusion that small species were more tolerant. This is not supported by the present study as the two species A. minutissimum and E. minima which have the smallest cellular biovolumes (Table 1) were not more tolerant to diuron than larger forms.

\section{Relationship between species sensitivity and in situ distribution}

The way diatom species are distributed along the contamination gradient of the Morcille River should reflect their sensitivity to diuron. Indeed, high concentrations of diuron were measured at the downstream site at the time of periphyton sampling in 2008 and in 2009 (Table 2). Variations in relative abundance of the species $F$. capucina and $N$. palea are consistent with their measured sensitivity (Fig. 4). However the species of intermediate sensitivity had either lower (A. minutissimum, E. minima) or higher $(N$. linearis, $N$. lanceolata) abundance at the polluted downstream site. This indicates that diuron was probably not the main factor determining diatom distribution in the pollution gradient. The diatoms may be under the dominant influence of another toxicant which would affect them differently. Copper is considered the second main toxic stressor in the river ${ }^{9}$ and could be a determining factor. However, although $\mathrm{Cu}$ concentrations were considerable at the downstream site (Table 2), it was shown that copper is much less toxic to diatoms than diuron. ${ }^{12}$ Finally it 
Table 2 Chemical conditions at the two sites of the river (up and downstream) for the two periods under study. Mean values of 5 measurements (standard error in brackets, DOC: dissolved organic carbon). All data except Cu concentrations are from Pesce et al. ${ }^{19}$ and Morin et al. ${ }^{2}$

\begin{tabular}{|c|c|c|c|c|c|c|c|c|c|c|c|c|c|c|}
\hline & \multicolumn{2}{|l|}{$\mathrm{pH}$} & \multicolumn{2}{|c|}{$\begin{array}{l}\text { Conductivity/ } \mu \mathrm{S} \\
\mathrm{cm}^{-1}\end{array}$} & \multicolumn{2}{|c|}{$\mathrm{DOC} / \mathrm{mg} \mathrm{L}^{-1}$} & \multicolumn{2}{|c|}{$\mathrm{PO}_{4} / \mathrm{mg} \mathrm{L}^{-1}$} & \multicolumn{2}{|c|}{$\mathrm{NO}_{3} / \mathrm{mg} \mathrm{L}^{-1}$} & \multicolumn{2}{|c|}{$\begin{array}{l}\text { Diuron/ } \mu \mathrm{g} \\
\mathrm{L}^{-1}\end{array}$} & \multicolumn{2}{|c|}{$\mathrm{Cu} / \mu \mathrm{g} \mathrm{L}^{-1}$} \\
\hline & 2008 & 2009 & 2008 & 2009 & 2008 & 2009 & 2008 & 2009 & 2008 & 2009 & 2008 & 2009 & 2008 & 2009 \\
\hline Upstream & $7.1(0.3)$ & $7.3(0.1)$ & $129(4)$ & $152(6)$ & $2.3(0.6)$ & $3.5(0.8)$ & $0.12(0.02)$ & $0.02(0.00)$ & $5.9(0.2)$ & $1.44(0.1)$ & $<\mathrm{q}_{.} \mathrm{l}^{a}{ }^{a}$ & $0.31^{c}$ & $0.7(0.1)$ & $1.0(0.3)$ \\
\hline Downstream & $7.3(0.2)$ & $7.7(0.1)$ & $210(11)$ & 219 (13) & $3.8(0.2)$ & $6.2(1.3)$ & $0.29(0.02)$ & $0.11(0.02)$ & $6.5(0.4)$ & $1.94(0.4)$ & $6.7^{b}$ & $4.6^{c}$ & $15^{b}$ & $10.8(3.4)$ \\
\hline
\end{tabular}

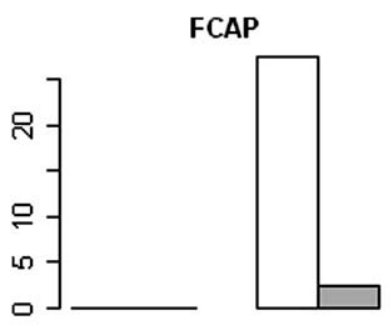

ADMI
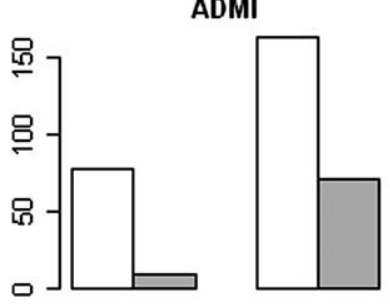

EOMI
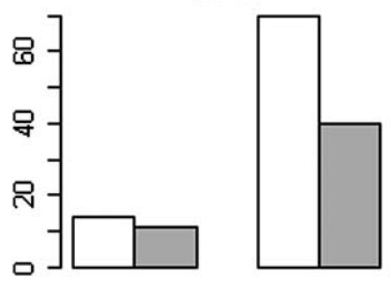

ENME

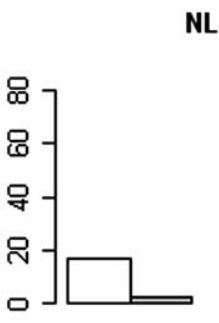

NLAN

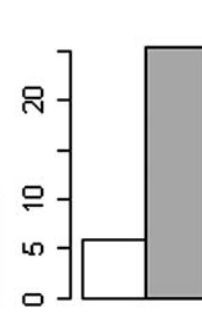

NLIN
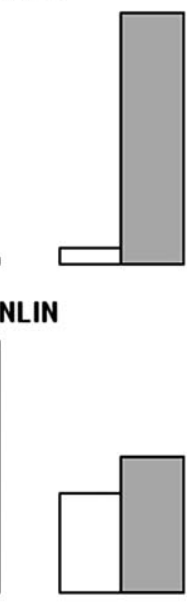

NPAL
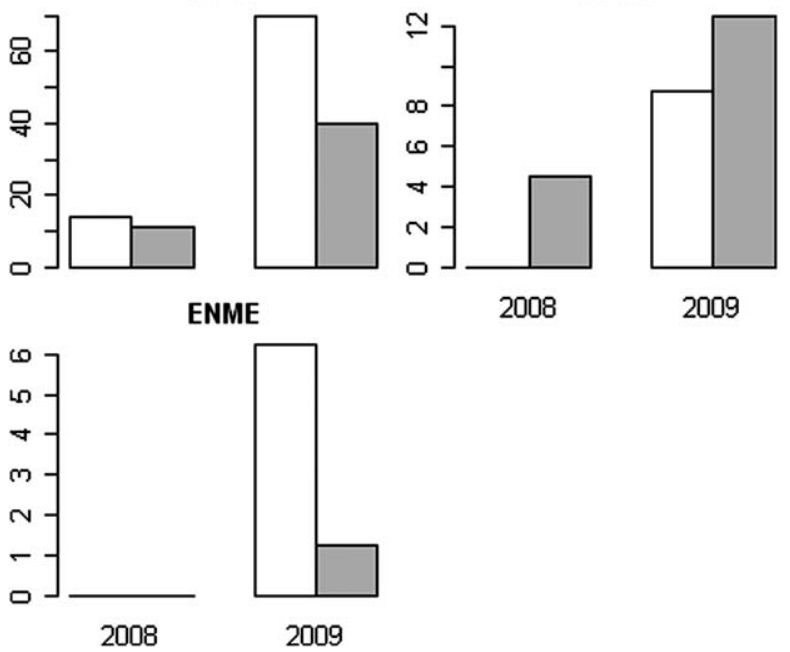

Fig. 4 Diatom relative abundance (in \%) in periphyton collected in spring 2008 and 2009 at the upstream (white bars) and the downstream (grey bars) sites. Species abbreviations are given in Table 1.

is also likely that the trophic effect linked to nutrients might dominate over the effect of contaminants.

Indeed nutrient as well as dissolved organic carbon concentrations increased going downstream in the Morcille River (Table 2). This was shown to result in a decrease of the Specific Polluosensitivity Index (SPI), ${ }^{2}$ a biological diatom-based index which is used to assess trophic and saprobic pollution. ${ }^{29}$ The specific sensitivity derived from this index accounts better for the distribution of the species tested in the Morcille River than the EC50 of diuron does (Table 1, Fig. 5). Indeed the high SPI values of $F$. capucina, A. minutissimum and $E$. neomesianum can explain why these species have a preference for upstream water whereas the high value of $N$. palea which is known as a hyper-eutraphentic species ${ }^{30}$ may be the reason behind the higher abundance of the taxon at the nutrient-enriched downstream site. Finally, it seems that the trophic level determines species distribution more than the concentration of diuron in the river, even if the herbicide probably influences diatom community composition too. In a channel experiment, Ricart et al. ${ }^{15}$ showed that diuron alone modified the composition of periphytic diatom communities. After 1 month at a concentration of $7 \mu \mathrm{g} \mathrm{L}^{-1}, F$. capucina was found only in control conditions (though at very low abundance), the abundance of $A$. minutissimum was reduced and $N$. palea appeared indifferent to the presence of diuron.

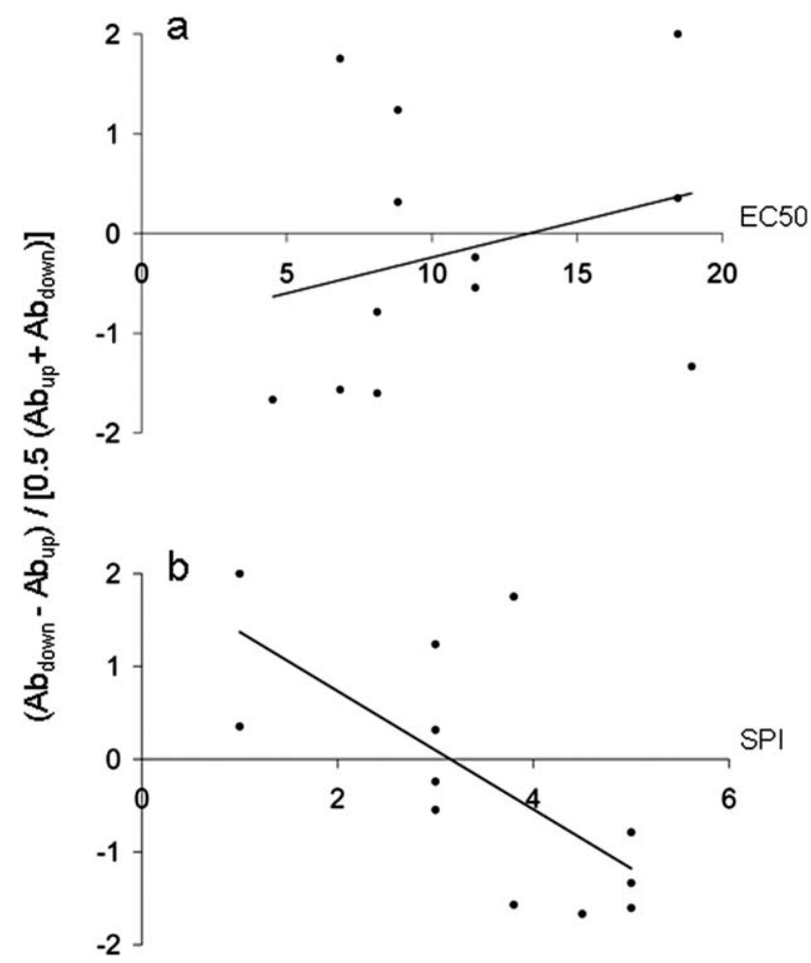

Fig. 5 Plot of the relative abundances of the species tested from up to downstream (weighted by the mean abundance) versus measured EC 50 of diuron (a) and the Specific Polluosensitivity Index (SPI) (b). SPI explains much more variance $\left(R^{2}=0.46, p=0.016\right)$ than $\operatorname{EC50}\left(R^{2}=0.08, p=0.39\right)$. 


\section{Conclusions}

Unlike with other bioindicator organisms, the diatom sensitivity to toxicants can be easily tested. This study showed significant variations in sensitivity of common species. EC50 values could be used as a basis for the construction of a diatom toxicity index that could indicate a probability of water contamination taking into account the interference of trophic factors. However, the high diversity of diatom species and toxicants could restrict the use of such ecotoxicological tests for the validation of simplification hypotheses as regards to diatom life forms and toxicant modes of action. Indeed the relevance of diatom classification into life forms to indicate contaminations has to be confirmed. It would be also interesting to check whether the differences in the sensitivity of diatoms are the same for pesticides having the same physiological mode of action. Toxic bioindication could be used as a complement to classic trophic bioindication as the sensitivity to toxicants seems to be independent of the sensitivity to trophic pollution as shown by the example of E. neomesianum in this study. Finally, further work should investigate the extent to which diatom species can adapt to toxic stress as variations in sensitivity to pollution at the infraspecific level could seriously impair toxic bioindication reliability.

\section{Acknowledgements}

The authors wish to thank Gaël Gilbert, Cécile Nassiet and Damien Valade for their help with the tests, Brigitte Delest for the preparation of the pesticide samples and the technical staff of Cemagref in Lyon for their kind presentation of the study area.

\section{References}

1 European Commission, Off. J. Eur. Communities: Legis., 2000, 327, $1-72$.

2 S. Morin, S. Pesce, A. Tlili, M. Coste and B. Montuelle, Ecol. Indic., 2010, 10, 419-426.

3 F. Rimet and A. Bouchez, Ecol. Indic., 2010, 11, 489-499.

4 V. Roubeix, N. Mazzella, F. Delmas and M. Coste, Vie et Milieu, 2010, 60, 233-241.

5 S. Morin, M. Bottin, N. Mazzella, F. Macary, F. Delmas, P. Winterton and M. Coste, Aquat. Toxicol., 2009, 94, 28-39.
6 M. Rabiet, C. Margoum, V. Gouy, N. Carluer and M. Coquery, Environ. Pollut., 2010, 158, 737-748.

7 J. S. C. Wessels and R. Vanderveen, Biochim. Biophys. Acta, 1956, 19, $548-549$.

8 A. Moncada, Environmental Fate of Diuron, Department of Pesticide Regulation, Environmental Monitoring Branch, Sacramento, 2004, http://www.cdpr.ca.gov/docs/emon/pubs/fatememo/diuron.pdf.

9 A. Dubois, L. Lacouture and C. Feuillet, in Etudes et Documents, Commissariat Général au Développement Durable, Paris, 2010, vol. 26.

10 S. M. Bengtson Nash, P. A. Quayle, U. Schreiber and J. F. Müller, Aquat. Toxicol., 2005, 72, 315-326.

11 G. Gatidou and N. S. Thomaidis, Aquat. Toxicol., 2007, 85, 184-191.

12 A. Koutsaftis and I. Aoyama, Environ. Toxicol., 2006, 21, 432-439.

13 M. Magnusson, K. Heimann, P. Quayle and A. P. Negri, Mar. Pollut. Bull., 2010, 60, 1978-1987.

14 T. A. Hollister and G. E. Walsh, Bull. Environ. Contam. Toxicol., 1973, 9, 291-295.

15 M. Ricart, D. Barceló, A. Geiszinger, H. Guasch, M. L. d. Alda, A. M. Romaní, G. Vida, M. Villagrasa and S. Sabater, Chemosphere, 2009, 76, 1392-1401.

16 U. Dorigo, A. Berard, F. Rimet, A. Bouchez and B. Montuelle, Aquat. Toxicol., 2010, 98, 396-406.

17 S. Pesce, C. Margoum and B. Montuelle, Water Res., 2010, 44, 19411949.

18 B. Montuelle, U. Dorigo, A. Berard, B. Volat, A. Bouchez, A. Tlili, V. Gouy and S. Pesce, Hydrobiologia, 2010, 657, 123-141.

19 S. Pesce, S. Lissalde, D. Lavieille, C. Margoum, N. Mazzella, V. Roubeix and B. Montuelle, Aquat. Toxicol., 2010, 99, 492-499.

$20 \mathrm{~K}$. Krammer and H. Lange-Bertalot, Bacillariophyceae 1. Teil: Naviculaceae, p. 876; 2. Teil: Bacillariaceae, Epithemiaceae, Surirellaceae, p. 596; 3. Teil: Centrales, Fragilariaceae, Eunotiaceae, p. 576; 4. Teil: Achnanthaceae. Kritische Ergänzungen zu Navicula (Lineolatae) und Gomphonema, p. 437, G. Fischer Verlag, Stuttgart, 1986-1991.

21 R. R. L. Guillard and C. J. Lorenzen, J. Phycol., 1972, 8, 10-14.

22 V. Roubeix, F. Mazzella, B. Méchin, M. Coste and F. Delmas, Ann. Limnol. - Int. J. Lim., DOI: 10.1051/limn/2011009.

23 S. Lissalde, N. Mazzella, V. Fauvelle, F. Delmas, P. Mazellier and B. Legube, J. Chromatogr., A, 2011, 1218, 1492-1502.

24 R. Ihaka and R. Gentleman, J. Comput. Graph. Stat., 1996, 5, 299 314.

25 E. J. Calabrese, Environ. Pollut., 2005, 138, 378-411.

26 S. Rotter, F. Sans-Piché, G. Streck, R. Altenburger and M. SchmittJansen, Aquat. Toxicol., 2011, 101, 228-236.

27 S. I. Passy, Aquat. Bot., 2007, 86, 171-178.

28 A. Tuji, Phycol. Res., 2000, 48, 75-84.

29 J. Prygiel, L. Leveque and R. Iserentant, Rev. Sci. Eau, 1996, 9, $97-$ 113.

30 H. Van Dam, A. Mertens and J. Sinkeldam, Neth. J. Aquat. Ecol., 1994, 28, 117-133.

31 C. Lecointe, M. Coste and J. Prygiel, Hydrobiologia, 1993, 269-270, $509-513$. 